\title{
PENERAPAN MODEL PEMBELAJARAN AUDITORY, INTELLECTUALY, REPETITION (AIR) TERHADAP HASIL BELAJAR KOGNITIF MATEMATIKA
}

\author{
Nurapni Sopia \\ Program Studi Pendidikan Matematika STKIP Persada Khatulistiwa Sintang \\ e-mail :nurapni22sopia@gmail.com.
}

\begin{abstract}
This research was conducted in primary school number 2 Sintang to assess the application of Auditory, Intellectualy, Repetition (AIR) learning model toward the results of cognitive learning math for grade $V$ students of primary school number 2 Sintang, in academic year 2018/2019. It is Quantitative research method. The form of research is an eksperiment in the form of a quasi eksperimental design with pretest-posttest design research control group design. The subjects of this research is grade $V$ students of primary school number 2 Sintang, which consists of 46 students. The sample in this study were determined by purposive sampling technique. In collecting the data the researcher used measurement, direct observation, observation, indirect and the study dokumentation. The data collection tools in the form of reserved tests, observation sheets, question, form and dokumentation. After analyzingusing t-test 18 spss programs, with $a=0.05$ and $d k n 1$ $+n 2-2$ then obtained $t_{\text {count }}>t_{\text {table }}=18,178>2.074$ mean Ha received and Ho rejected it can be concluded that there are significant differences before and after application of the Auditory, Intellectualy, Repetition (AIR) learning model results of cognitive learning math of grade $V$ students of primary school number 2 Sintang, in academic year 2019.
\end{abstract}

Keywords : Model AIR, Learning Outcomes

Abstrak: Penelitian ini dilaksanakan di Sekolah Dasar Negeri 2 Sintang yang bertujuan untuk mengkaji Penerapan Model Pembelajaran Auditory, Intellectualy, Repetition (AIR) Terhadap Hasil Belajar Kognitif Matematika Siswa Kelas V Sekolah Dasar Negeri 2 Sintang Tahun Pelajaran 2018/2019. Metode penelitian menggunakan metode penelitian kuantitatif dengan bentuk penelitian eksperimen yakni Quasi Eksperimentel Design dan desain penelitian pretest-posttest control group design. Populasi dalam penelitian ini adalah siswa kelas V Sekolah Dasar Negeri 2 Sintang dengan jumlah 46 siswa. Sampel dalam penelitian ini ditentukan dengan teknik sampling purposive. Teknik pengumpulan data menggunakan teknik pengukuran, observasi langsung, observasi tak langsung dan studi dokumentasi. Alat pengumpulan data berupa soal tes, lembar observasi, angket, dan dokumentasi. Setelah dianalisis menggunakan uji t-test dengan program SPSS 18, dengan $\alpha=0,05$ dan $d k n_{1}+n_{2}-2$ maka diperoleh $t_{\text {hitung }}>t_{\text {tabel }}=18,178>2,074$ artinya Ha diterima dan Ho ditolak disimpulkan bahwa terdapat perbedaan yang signifikan sebelum dan sesudah penerapan model pembelajaran Auditory, Intellectualy, Repetition (AIR) terhadap hasil belajar kognitif matematika siswa kelas V Sekolah Dasar Negeri 2 Sintang Tahun Pelajaran 2018/2019.

Kata Kunci: Model AIR, Hasil Belajar 


\section{PENDAHULUAN}

Guru merupakan faktor yang penting dalam pendidikan yang berfungsi dalam meningkatkan kualitas pendidiikan. Melalui proses pendidikan guru sebagai pendidik harus mampu memberikan bimbingan pada peserta didiknya agar memperoleh pengetahuan baru (Sardiman, 2014). Guru hendaknya dapat memfasilitasi siswanya untuk belajar secara maksimal dengan menggunakan berbagai model, metode, pendekatan, strategi, taktik, teknik, media dan sumber belajar yang tersedia dan dapat digunakan dalam pembelajaran matematika. Meskipun demikian tidak mudah bagi peserta didik untuk bisa mempelajari matematika sehingga siswa memiliki pendapat tersendiri tentang cara penyelesain masalah matematika yang belum tentu tepat kebenarannya. Oleh sebab itu, seorang guru perlu memperhatikan dan dapat memilih model pembelajaran yang sesuai dengan kondisi peserta didik agar dapat mengingat, memahami, dan menerapkan pembelajaran yang diberikan oleh guru dalam kehidupan sehari-hari mereka.

Analisis awal terhadap hasil belajar kognitif matematika siswakelas V SDN 2 Sintang yaitu belum mampu memahami, dan menerapkan sendiri makna dari pelajaran matematika yang dipelajari sehingga mengalami kesulitan dalam menyelesaikan soal-soal yang lebih sulit terutama pada soal dengan tingkatan kognitif matematika. Peserta didik hanya bisa menyelesaikan soal yang serupa dengan contoh yang telah diberikan oleh guru. Selain itu, model pembelajaran yang digunakan oleh guru belum optimal untuk meningkatkan hasil belajar kognitif siswa karena pembelajaran masih terpusat pada guru (teacher center) dan disertai dengan pengajaran yang masih menggunakan metode konvensional sehingga bedampak pada rendahnya hasil belajar kognitif matematika.

Hasil belajar yang rendah tersebut mengakibatkan guru harus menjelaskan ulang materi yang telah disampaikan, sementara waktunya sangat terbatas. Hasil belajar kognitif siswa yang rendah dapat dilihat dari nilai kognitif yang diperoleh masih sangat rendah dan banyak yang belum mencapai ketuntasan minimal yaitu 62, pada kelas VA yang akan dijadikan kelas eksperimen ada 11 siswa yang tuntas atau yang sudah mendapat nilai di atas kriteria ketuntasan minimal dan ada 12 siswa yang tidak tuntas, dan pada kelas VB yang akan dijadikan kelas kontrol, 13 siswa yang tuntas dan 10 siswa yang belum mencapai kriteria ketuntasan minimal yang ditentukan di sekolah tersebut. Oleh sebab itu perlu adanya upaya yang dilakukan untuk mencapai kriteria ketuntasan yang dimaksud. Satu diantaranya adalah penggunaan model dalam proses pembelajaran.

Pemilihan model pembelajaran yang tepat merupakan kunci keberhasilan dalam sebuah proses dan tujuan dari pembelajaran. Salah satu model pembelajaran yang dapat digunakan adalah model pembelajaran Auditory, Intellectually, Repetition (AIR), Huda (2014) Pembelajaran dengan Model AIR merupakan model pembelajaran yang menekankan tiga aspek, yaitu Auditory (belajar dan mendengar), Intellectualy (belajar dengan berpikir), dan Repetition 
(pengulangan), dari ketiga aspek tersebut maka akan dapat menciptakan suatu pembelajaran yang nantinya akan mampu dalam meningkatkan hasil belajar kognitif siswa dan juga aktivitas belajar siswa.

Pada hasil penelitian Manurung (2015) yang menjadi acuan menyatakan model pembelajaran AIR dapat meningkatkan kreativitas dan hasil belajar matematika siswa. Hal ini dapat diketahui bahwa terdapat perbedaan hasil belajar siswa sebelum dan sesudah penerapan model pembelajaran AIR.

Berdasarkan latar belakang yang telah dipaparkan masalah dalam penelitian ini (a) adakah perbedaan yang signifikan hasil belajar kognitif matematika siswa kelas $\mathrm{V}$ pada pengukuran awal (pretest) kelas eksperimen dan kelas kontrol, (b) adakah perbedaan yang signifikan hasil belajar kognitif matematika siswa kelas $\mathrm{V}$ pada pengukuran akhir (posttest) kelas eksperimen dan kelas kontrol, (c) adakah perbedaan yang signifikan hasil belajar kognitif matematika siswa kelas V pada pengukuran awal (pretest) dan pengukuran akhir (posttest) pada kelas kontrol, (d) adakah perbedaan yang signifikan hasil belajar kognitif matematika siswa kelas $\mathrm{V}$ pada pengukuran awal (pretest) dan pengukuran akhir (posttest) kelas eksperimen, (e) seberapa besar respon siswa kelas $\mathrm{V}$ setelah diterapkan model pembelajaran AIR di kelas eksperimen.

Adapun tujuan penelitian ini adalah sebagai berikut (a) mengetahui perbedaan antara hasil belajar kognitif siswa kelas $\mathrm{V}$ pada pengukuran awal (pretest) kelas eksperimen dan kelas kontrol, (b) mengetahui perbedaan antara hasil belajar kognitif siswa kelas $\mathrm{V}$ pada pengukuran akhir (posttest) kelas eksperimen dan kelas kontrol, (c) mengetahui perbedaan antara hasil belajar kognitif siswa kelas $\mathrm{V}$ pada pengukuran awal (pretest) dan pengukuran akhir (posttest) di kelas kontrol, (d) mengetahui perbedaan antara hasil belajar kognitif siswa kelas $\mathrm{V}$ pada pengukuran awal (pretest) dan pengukuran akhir (posttest) di kelas eksperimen, (e) mengetahui seberapa besar respon siswa kelas $\mathrm{V}$ setelah diterapkan model pembelajaran AIR di kelas eksperimen.

\section{METODE}

Metode penelitian yang digunakan dalam penelitian ini adalah metode eksperimen. Sedangkan bentuk penelitian yang digunakan dalam penelitian ini adalah quasi experimental design. Quasi experimental design menggunakan pretest-posttest control group design. Penelitian ini diaksanakan di SDN 2 Sintang tahun pelajaran2018/2019.

Populasi dalam penelitian ini adalah seluruh siswa kelas V SDN 2 Sintang dengan jumlah siswa sebanyak 46 orang. Penentuan sampel dalam penelitian ini menggunakan Non Probality Sampling dengan menggunakan teknik Purposive Sampling, yaitu Teknik penentuan sampel dengan pertimbangan tertentu. Hasil belajar kognitif matematika siswa diperoleh melalui pretest dan posttest siswa.Selanjutnya dilakukan uji prasyarat yaitu, uji normalitas dan uji homogenitas, uji ini dilakukan untuk mengetahui data normal dan homogen yang digunakan. Setelah data 
nomal dan homogen maka selanjutnya dilakukan uji hipotesis, yaitu uji t, uji t ini digunakan untuk menjawab uji hipotesis yang ada dalam penelitian.

\section{HASIL DAN PEMBAHASAN}

\section{Hasil Belajar Kognitif Siswa AIR}

Penerapan model pembelajaran AIR memberikan dampak yang baik dalam meningkatkan hasil belajar kognitif matematika siswa. Hal ini dapat dilihat dari hasil tes kemampuan pemahaman konsep matematika siswa pada kelas sampel yang menunjukkan adanya perbedaan antara siswa yang dibelajarkan dengan model AIR dengan siswa yang dibelajarkan dengan model konvensional. Perbedaan hasi belajar siswa antara kelas eksperimen dan kelas kontrol juga dapat dilihat pada Gambar 1.

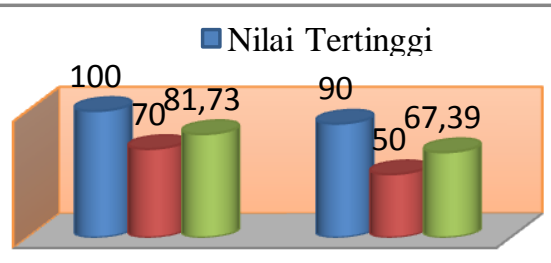

Kelas EksperimerKelas Kontrol

\section{Gambar 1 Perbedaan hasil Posttest kelas eksperimen dan kontrol}

Perbedaan posttest kelas eksperimen dan kontrol dapat dilihat dari nilai rata-rata posttest siswa kelas eksperimen adalah 81,73 dengan nilai tertinggi yaitu 100 , serta nilai terendah yaitu 70, sedangkan kelas kontrol rata-ratanya 67,39 dengan nilai tertinggi yaitu 90, dan nilai terendah yaitu 50. Berdasarkan nilai tersebuat maka di lakukan Uji normalitas pada pengukuran akhir (posttest) kelas eksperimen dan kelas kontrol dengan menggunakan uji kolmogrov smirnov menggunakan SPSS versi 18. Hasil yang diperoleh sebesar 0,049> nilai signifikansi sebesar 0,05 pada kelas eksperimen dan pada kelas kontrol adalah $0,110>$ nilai signifikansinya 0,05 .

Berdasarkan hasil tersebut sesuai dengan kreteria ketentuan nilai signifikan normaslitas dengan menggunakan uji kolmogrov smirnov dapat disimpulkan bahwa data posttest kelas eksperimen dan kelas kontrol berdistribusi normal. Uji homogenitas pada pengukuran akhir (posttest) kelas eksperimen dan kelas kontrol dengan uji $\mathrm{F}$ menggunakan SPSS versi 18. Hasil yang diperoleh Sig. $\quad$ sebesar $0,619>\quad$ nilai signifikansi sebesar 0,05 (5\%). Berdasarkan hasil tersebut sesuai dengan kreteria ketentuan nilai signifikan F dengan menggunakan SPSS versi 18.

Tabel 1 Perbedaan hasil belajar kelas eksperimen dan kelas kontrol

\begin{tabular}{|c|c|c|c|c|c|c|}
\hline Posttest & Dk & thitivng & $t_{\text {tabel }}$ & $\begin{array}{l}\text { sig. (2- } \\
\text { tailed) }\end{array}$ & $\alpha$ & Keterangan \\
\hline Eksperimen & \multirow[t]{2}{*}{44} & \multirow[t]{2}{*}{5,918} & \multirow[t]{2}{*}{2,015} & \multirow[t]{2}{*}{0,000} & \multirow[t]{2}{*}{0,05} & \multirow{2}{*}{$\begin{array}{l}\mathrm{H}_{2} \text { diterima } \\
\text { dan } \mathrm{H}_{0} \\
\text { ditololak }\end{array}$} \\
\hline Kontrol & & & & & & \\
\hline
\end{tabular}

Berdasarkan tabel 1 dapat dilihat bahwa $t_{\text {hitung kelas eksperimen dan kelas kontrol }}$ adalah 5,918; sementara $t_{\text {tabel }}$ pada taraf signifikansi $5 \%$ dengan $d k$ kontrol adalah 5,918 , sementara $t_{\text {tabel }}$ pada taraf signifikansi $5 \%$ dengan $d k$ berjumlah 44 adalah 2,015. Karena $t_{\text {hitung }}>t_{\text {tabel }}$, sesuai dengan kriteria pengujian maka dapat disimpulkan bahwa $H_{o}$ ditolak dan $H_{a}$ diterima. Selain itu berdasarkan hasil perhitungan tersebut juga 
5,918; sementara $t_{\text {tabel }}$ pada taraf signifikansi 5\% dengan $\mathrm{dk}$ berjumlah 44 adalah 2,015. Karena $t_{\text {hitung }}>t_{\text {tabel }}$, sesuai dengan kriteria pengujian maka dapat disimpulkan bahwa $H_{o}$ ditolak dan $H_{a}$ diterima. Selain itu berdasarkan hasil perhitungan tersebut jugadiperoleh nilai sig. $(2-$ tailed $)$ menggunakan SPSS versi 18 sebesar 0,000, sementara nilai kriteria signifikansi adalah 5\% atau sebesar 0,05. Karena nilai sig.(2tailed $)<0,05$; diperoleh nilai sig. $(2-$ tailed) menggunakan SPSS versi 18 sebesar 0,000 , sementara nilai kriteria signifikansi adalah $5 \%$ atau sebesar 0,05 . Karena nilai sig. $(2-$ tailed $)<0,05$,sesuai dengan kreteria pengujian maka dapat disimpulkan bahwa terdapat perbedaan yangsignifikan antar posttest kelas eksperimen dan kelas kontrol.

Dari uraian tersebut, dapat kita ketahui bahwa posttest pada kelas eksperimen dan kelas kontrol berdasarkan nilai yang diproleh yaitu sangat signifikan. Hal ini disebabkan karena adanya perlakuan yang diberikan pada kelas eksperimen yaitu pembelajaran dengan menggunakan model pembelajaran AIR, pembelajaran menggunakan model pembelajaran AIR merupakan pembelajaran yang dapat melatih pendengaran dan keberanian siswa untuk mengungkapkan pendapat (Auditory), melatih siswa untuk menyelesaikan masalah secara kreatif (Intellectually), melatih siswa untuk mengingat kembali tentang materi yang telah dipelajari (Repetition) dan dapat menjadikan siswa menjadi lebih aktif dan kreatif.
Sedangkan pada kelas kontrol hanya mengunakan pembelajaran konvensional, yaitu dengan menggunakan metode ceramah dan pengerjaan tugas secara individu. Setelah diberikan posttest, dari hasil uji $t$ tersebut dapat diketahui bahwa ada perbedaan yang signifikan antara posttest kelas eksperimen dan kelas kontrol, kesimpulan tersebut diperoleh peneliti karna signifikansi $t_{\text {hitung }}<t_{\text {tabel }}$, sesuai dengan kreteria pengujian maka $H_{O}$ ditolak dan $H_{a}$ diterima serta nilai signifikansi yang diperoleh yaitu $0,000<0,05$; maka berdasarkan teori signifikansi yaitu taraf signifikansi tertinggi adalah 5\%, dengan ini peneliti menyimpulkan bahwa ada perbedaan yang sangat signifikan antara Posttest kelas eksperimen dan kelas kontrol, selain itu kesimpulan dari pembahasan posttest eksperimen dan kontrol tersebut juga sesuai dengan kajian penelitian yang relevan dari Purnamasari (2014) yang hasil penelitiannya menunjukkan bahwa terdapat perbedaan hasil belajar matematika yang signifikan antara siswa yang dibelajarkan dengan model pembelajaran AIR dan siswa yang dibelajarkan dengan model pembelajaran konvensional, Prasetya (2016) hasil penelitiannya juga menyatakan bahwa model air mampu meningkatkan hasil belajar siswa.

\section{Respon siswa kelas $\mathbf{V}$ setelah diterapkan model pembelajaran AIR}

Model pembelajaran AIR merupakan pembelajaran dimana siswa dituntut aktif dalam pembelajaran bekerja sama dan berkomunikasi satu dengan yang lainnya, 
selain dituntut untuk dapat mendengar dengan baik, siswa juga di tuntut untuk dapat berfikir untuk menyelesaikan permasalahan yang diberikan guru yang berkaitan dengan materi, seperti mengerjakan lembar kerja siswa (LKS).Berikut tabel hasil respon siswa:

Tabel 2 Hasil angket respon siswa

\begin{tabular}{ccc}
\hline Skor Total & Persentase & Kategori \\
\hline 1770 & $88,50 \%$ & Sangat Tinggi \\
\hline
\end{tabular}

Dari tabel 2 dapat diketahuai respon siswa dengan diterapkan model pembelajaran AIR berdasarkan hasil peryataan persetujuan siswadari hasil angket diperoleh skor total 1770 dengan hasil persentase akhir 88,50\% dari persentase $100 \%$ yang diharapkan, persentase respon siswa terhadap model ini belum mencapai $100 \%$ dikarenakan ada beberapa siswa yang mungkin kurang menyukai model pembelajaran AIR, beberapa siswa ini kurang suka dengan model yang diterapkan diperkirakan karena kurang aktifnya siswa ini dalam proses pembelajaran dan tidak mau bergabung belajar bersama temanya.

Berdasarkan persentase respon yang ada dapat disimpulkan penilaian siswa terhadap penggunaan model pembelajaran AIR dalam proses belajar mengajar masuk kategori sangat tinggi. Hal ini di karenakan dalam pembelajaran menggunakan model pembelajaran AIR siswa terlibat aktif dalam proses belajar mengajar dan dapat melakukan interaksi dengan temannya serta dapat saling bertukar pikiran saat melakukan diskusi, dapat praktek secara lansung sehingga siswa dapat pengalaman yang nyata dan juga dalam proses pembelajaran menggunakan model ini siswa dapat belajar tanpa tekanan dan dapat merasa santai dan bergembira. Hasil penelitian peneliti tersebut sejalan dengan penelitian terdahulu oleh Nawafilah (2015) menyatakan bahwa pembelajaran dengan model AIR mendapat respon yang positif dari siswa, hal itu menunjukan bahwa siswa menyukai pembelajaran dengan menggunakan modelAIR. Pujiastutik (2016) berdasarkan hasil penelitiannya juga menyatakan bahwa pembelajaran dengan model ntellectually, AIR mendapat respon yang positif dari siswa, siswa merasa lebih nyaman belajar menggunakan model ini.

\section{SIMPULAN DAN SARAN}

Berdasarkan analisis data yang telah dilakukan dalam penelitian ini, maka diperoleh kesimpulan sebagai berikut: (1) Tidak terdapat perbedaan yang signifikan hasil belajar kognitif matematika siswa kelas $\mathrm{V}$ pada pretest kelas eksperimen dan kelas kontrol, dengan nilai sig. $\geq 0,05$ dengan nilai signifikansi sebesar $0,870 \geq 0,05$; maka $H_{o}$ diterima dan $H_{a}$ ditolak,(2) Terdapat perbedaan yang signifikan hasil belajar kognitif matematika siswa kelas $\mathrm{V}$ pada posttest kelas eksperimen dan kelas kontrol yaitu dengan taraf signifikansi $(\alpha)$ sebesar 0,05 atau 5\% makadiperolehnilai sig.sebesar $0,000<0,05$, maka $H_{o}$ ditolak dan $H_{a}$ diterima, (3) Terdapat perbedaan yang signifikan hasil belajar kognitif matematika siswa kelas $\mathrm{V}$ pada hasil pretest dan posttest kelas kontrol, berdasarkan perhitungan data pretest dan posttest pada kelas kontrol, dengan 
$\alpha=0,05$ maka diperoleh nilai sig. sebesar $0,000<0,05$, maka $H_{o}$ ditolak dan $H_{a}$ diterima, (4) Terdapat perbedaan yang signifikan hasil belajar kognitif siswa kelas V pada hasil pretest dan posttest pada kelas eksperimen, berdasarkan perhitungan data pretest dan posttest pada kelas eksperimen, dengan $\alpha=0,05$ siswa kelas $\mathrm{V}$ pada pretest kelas eksperimen dan kelas kontrol, dengan nilai sig. $\geq 0,05$ dengan nilai signifikansi sebesar $0,870 \geq 0,05$; maka $H_{0}$ diterima dan $H_{a}$ ditolak, (4) Terdapat perbedaan yang signifikan hasil belajar kognitif matematika siswa kelas $\mathrm{v}$ pada posttest kelas eksperimen dan kelas kontrol yaitu dengan taraf signifikansi $(\alpha)$ sebesar 0,05 atau 5\% maka diperoleh nilai sig. sebesar 0,000<0,05; maka $H_{o}$ ditolak dan $H_{a}$ diterima, (5)Terdapat perbedaan yang signifikan hasil belajar kognitif matematika siswa kelas $\mathrm{V}$ pada hasil pretest dan posttest kelas kontrol, berdasarkan perhitungan data pretest dan posttest pada kelas kontrol, dengan $\alpha=0,05$ maka diperoleh nilai sig. sebesar 0,000<0,05; maka $H_{o}$ ditolak dan $H_{a}$ diterima, (6)Terdapat perbedaan yang signifikan hasil belajar kognitif siswa kelas $\mathrm{V}$ pada hasil pretest dan posttest pada kelas eksperimen, berdasarkan perhitungan data pretest dan posttest pada kelas eksperimen, dengan $\alpha=0,05$ maka diperoleh nilai sig. sebesar 0,000<0,05; maka $H_{o}$ ditolak dan $H_{a}$ diterima, (7) Respon siswa dalam proses belajar mengajar dengan menggunakan model pembelajaran AIR berdasarkan data angket siswa diperoleh nilai persentase sebesar $87,9 \%$. masuk kategori Sangat Tinggi.

Berdasarkan hasil penelitian yang telah dilakukan oleh peneliti, maka peneliti memberikan saran. Saran bagi guru SD khususnya guru mata pelajaran matematika untuk dapat menerapkan model pembelajaran AIR dengan memilih materi yang sesuai dengan model AIR sebagai upaya alternatif untuk meningkatkan hasil belajar kognitif siswa.

\section{DAFTAR PUSTAKA}

Huda, Miftahul. 2014. Model-model pengajaran dan pembelajaran. Yogyakarta: Pustaka Pelajar.

Manurung, Sri Hariani. 2015. Upaya meningkatkan kreatifitas dan hasil belajar matematika siswa dengan menggunakan model Auditory, Intellctually, Repetition (AIR) pada siswa kelas viii mis negeri rantau prapat, Jurnal Edurech, 2(1):97-107.

Nawafilah, Nur Qomariyah. 2015. Penerapan pembelajaran dengan pendekatan auditory, intellectually, repetition (AIR) pada materi sifat-sifat bangun dan hubungan antar bangun di kelas v sekolah dasar, Jurnal. Ilmu Sosial Dan Humanira, 3(2): 1-7.

Prasetya, Rio. 2016. Penerapan model pembelajaran kooperatif tipe Auditory, Intellctually, Repetition (AIR) untuk meningkatkan hasil belajar pada kompetensi dasar menjelaskan instalasi lampu 
penerangan bangunan gedung siswa

kelas XI TIPTl SMK negeri 2 surabaya ,E-Journal Pendidikan Teknik Elekro, 5(2): 589-593.

Pujiastutik, hernik. 2016. Penerapan model pembelajaran auditory, intellectually, repetition (AIR) untuk meningkatkan hasil belajar siswa, Proceeding Biology Education Conference, 13(1): 515-518.

Purnamasari, Yurdiana Ika. 2014.Pengaruh model pembelajaran auditory, intellectually , ,repetition (AIR)terhadap prestasi belajar matematika pada materi aljabar.Skripsi. Jetis :Universitas Muhammadiyah Ponorogo

Sadirman. 2014. Interaksi dan Motivasi dalam Proses Belajar Mengajar. Jakarta: Grafindo Persada. 